\title{
RANCANGAN APLIKASI INVENTARISIR BAHAN PEMBUAT MUKENA PADA PT.TATUIS BOGOR DENGAN MENGGUNAKAN JAVA
}

\author{
Ega Shela Marsiani \\ Program Studi Informatika, Universitas Indraprasta PGRI \\ egashela@gmail.com
}

\begin{abstract}
Abstrak
Tujuan dari penelitian ini adalah untuk memberikan kemudahan bagi staff gudang dalam pengolahan data inventaris sehingga dapat memberikan informasi yang cepat, tepat dan akurat. Metode penelitian yang digunakan untuk perancangan sistem aplikasi ini adalah dengan menggunakan metode Grounded Research. Setelah penulis melakukan perancangan sistem aplikasi input data inventaris, akhirnya penulis dapat menarik kesimpulan bahwa aplikasi dengan menggunakan software Netbeans dan IReport menghasilkan tampilan lebih interaktif dan dapat memberikan kemudahan bagi staf gudang PT.Tatuis. PT. Tatuis juga menyediakan pelayanan yang sangat baik dan barang yang mereka produksi pun sangatlah berkualitas. Untuk mendapatkan hasil yang efektif dan efisien pendataan PT. Tatuis diperlukan sebuah sistem penyimpanan data yang baik dan user friendly. Namun dalam hal pendataan inventaris bahan baku yang akan diproduksi menjadi mukena.
\end{abstract}

Kata kunci : inventaris , bahan mukena, java desktop

\begin{abstract}
The purpose of the research is to provide the warehouse staff with convenience to process inventory data so that they can give fast, precise and accurate information. The research method used for the design of this application system is a Grounded Research method. After designing the system of inventory data input application, the researcher then draws a conclusion that the application using Netbeans and IReport softwares can generate more interactive appearance and provide convenience for the PT. Tatuis warehouse staff. Further, PT. Tatuis offers excellent service and produces the goods of high quality. Therefore, to make it more effective and efficient, PT. Tatuis needs a good and userfriendly data storage system to draw up the inventory of mukena fabric.
\end{abstract}

Keywords: inventory, mukena fabric, java desktop

\section{PENDAHULUAN}

\section{A. Latar Belakang Masalah}

PT. Tatuis bergerak dibidang fashion mukena yang berpusat di daerah Bogor, PT.Tatuis memiliki distributor yang tersebar di beberapa daerah. PT. Tatuis juga menyediakan pelayanan yang sangat baik dan barang yang mereka produksi pun sangatlah berkualitas.

Namun dalam hal pendataan inventaris bahan baku yang akan diproduksi menjadi mukena atau barang jadinya PT. Tatuis masih menggunakan Microsoft Excel. Hal ini tentu saja menyebabkan pendataan menjadi kurang optimal serta dalam hal pembuatan dan pencarian data menjadi semakin sulit. Adapun manfaat perancangan yakni merancang strategi untuk memecahkan masalah dan mengembangkan solusi yang tepat bagi permasalahan yang ada. Perancangan Sistem adalah termasuk bagaimana mengorganisasi sistem kedalam subsistemsubsistem, serta alokasi subsistemsubsistem ke komponen-komponen perangkat keras, perangkat lunak, serta prosedur-prosedur [1].

Dengan demikian pendataan PT.Tatuis dapat menjadi lebih terstruktur dan cepat, diperlukan sebuah sistem penyimpanan data yang baik. Suatu aplikasi pemrograman sangat dibutuhkan pada 
suatu institusi, instansi dan lembagalembaga lainnya karena dalam perkembangan zaman yang semakin modern saat ini komputer sudah dapat dijumpai di setiap tempat. Perkembangan teknologi komputer yang sangat pesat ini, khususnya di bidang perangkat lunak, membuat komputer menjadi semakin user friendly dan telah menjadikannya suatu prioritas bagi kalangan tertentu, misalnya kalangan bisnis, pemerintahan dan lain-lain. Karena kualitas informasi tergantung dari tiga hal yang sangat dominan yaitu keakuratan informasi, ketepatan waktu, dan relevan [2].

Sebagai dasar penyelesaian masalah dan solusi pemecahan masalah maka dibutuhkan suatu aplikasi pemrograman untuk pendataan inventaris bahan secara otomatis, Aplikasi ini dapat digunakan untuk mewujudkan suatu pengolahan data yang sistematis yang tentunya semakin maju sarana dan prasarananya selain itu digunakan juga untuk menunjang kegiatan operasional di PT. Tatuis.

Nilai informasi ditentukan oleh 2 (dua) hal, yaitu manfaat dan biaya untuk mendapatkannya. Suatu informasi memiliki nilai bila lebih efektif dengan biaya mendapatkannya. Pengukuran nilai informasi biasanya dihubungkan dengan analisis cost effectiveness atau cost benefit [4].

\section{B. Tujuan Penelitian}

1. Membangun dan mengembangkan sistem inventarisir pada PT.Tatuis.

2. Mengindentifikasi persediaan bahan baku pada PT.Tatuis secara sistematis.

\section{Manfaat dari Penelitian}

Mempermudah pengecekan dan pembuatan laporan data bahan yang berada di gudang bahan mentah dan bahan dalam proses. karena Informasi yang diperoleh dari pengolahan data dapat dinilai berdasarkan sifatnya [3].

\section{METODE PENELITIAN}

Metode penelitian yang digunakan oleh penulis dalam artikel jurnal string ini adalah metode grounded (grounded research) yaitu suatu metode penelitian berdasarkan pada fakta dan menggunakan analisis perbandingan dengan tujuan mengadakan generalisasi empiris, menetapkan konsep, membuktikan teori, mengembangkan teori, pengumpulan dan analisis data dalam waktu yang bersamaan. Setelah mengumpulkan data, penulis melanjutkan proses penelitian sesuai dengan langkah-langkah pokok yang digunakan pada metode ini, yaitu menentukan masalah yang ingin diselidiki, mengumpulkan data atau informasi yang ada pada kondisi saat ini dan dari bahanbahan lain yang berkaitan, menganalisis dan menjelaskan masalah yang ditemukan serta membuat laporan hasil penelitian.

\section{A. Studi Kepustakaan Research)}

Pengumpulan data dan informasi dari kutipan buku-buku, artikel-artikel, hasil laporan, serta bahan lainnya yang berhubungan dengan penulisan ini. Dari bahan-bahan tersebut diambil teori-teori yang dapat dijadikan landasan untuk menganalisa masalah yang diketahui dalam penelitian dan digunakan untuk menyelesaikan masalah tersebut.

\section{B. Studi Lapangan (Field Research)}

1. Wawancara

PT.Tatuis Cahaya Internasional. Penulis mengajukan pertanyaan mengenai sistem gudang pada perusahaan tersebut.

\section{Observasi}

Penulis berkunjung ke perusahaan untuk melihat keadaan nyata untuk memperoleh sistem yang berjalan sehingga penulis memperoleh gambaran nyata tentang kelemahan dan peluang yang ada saat proses berjalan. 


\section{HASIL DAN PEMBAHASAN}

\section{A. Dekomposisi Fungsi}

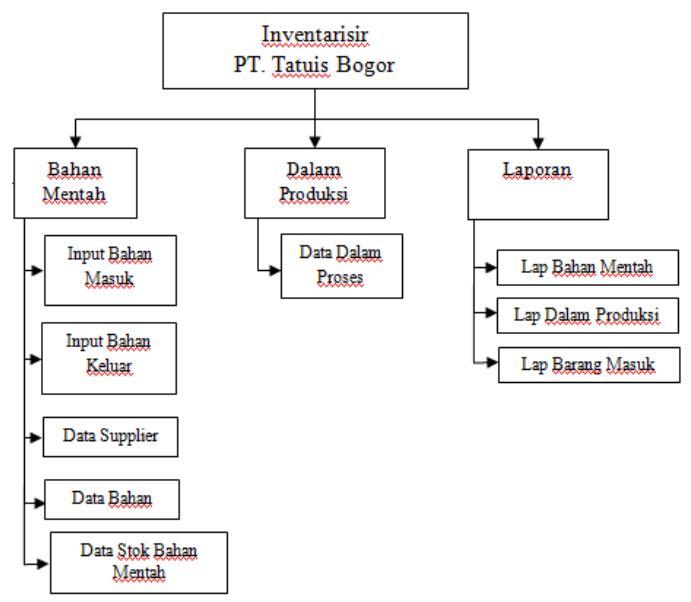

Gambar 1. Dekomposisi Fungsi

B. Diagram Alir Data (DAD) Konteks, Nol dan Rinci

1. Diagram Konteks

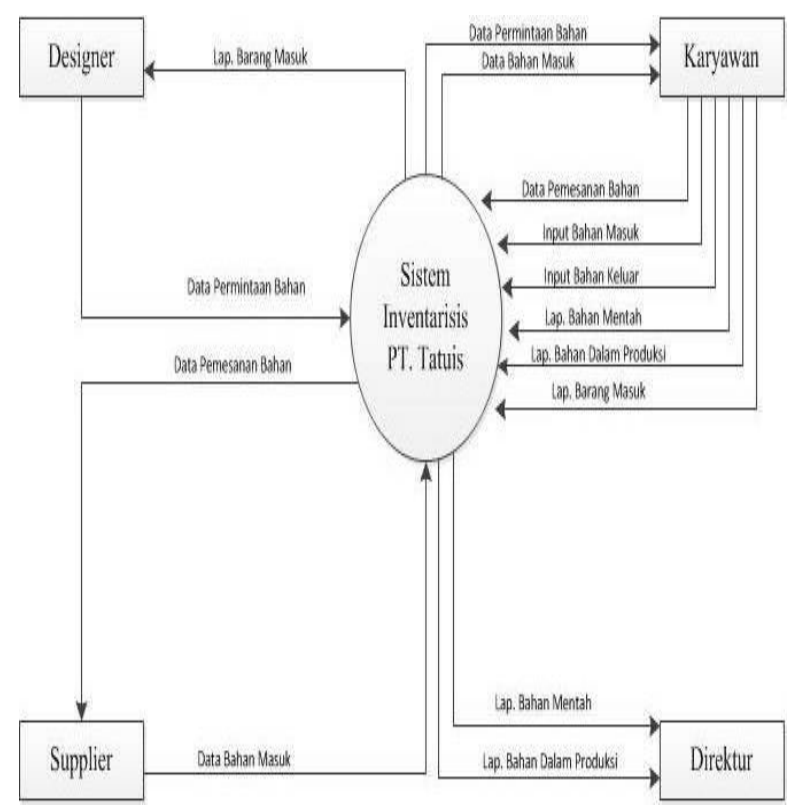

Gambar 2. Diagram Konteks
2. Diagram Nol

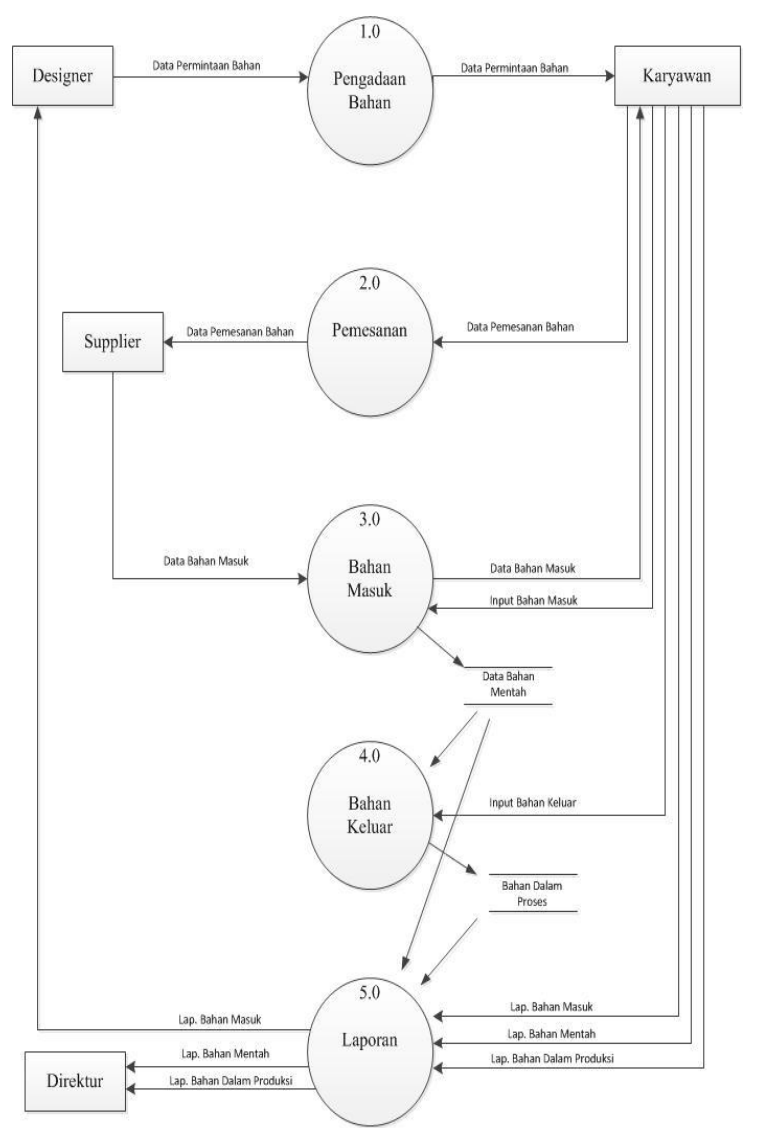

Gambar 3. Diagram Nol

3. Diagram Rinci

a) Diagram Rinci untuk Proses 3.0 Bahan Masuk

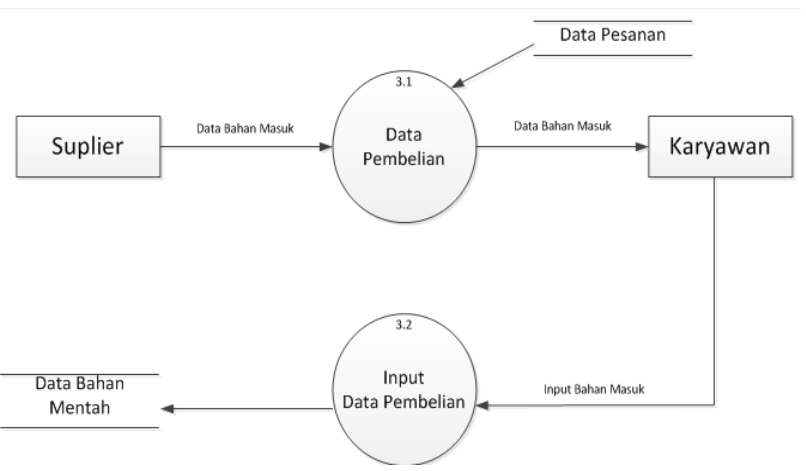

Gambar 4. Diagram Rinci Proses 3.0 
b) Diagram Rinci untuk Proses 5.0 Laporan

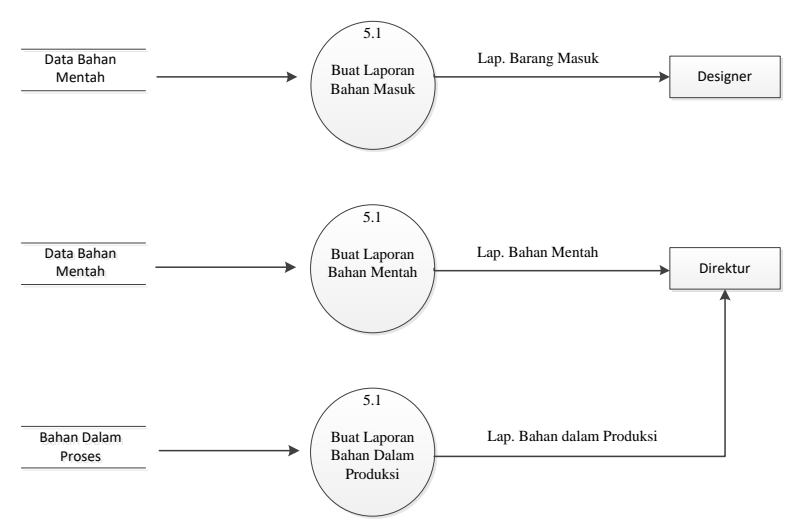

Gambar 5. Diagram Rinci Proses 5.0

C. Rancangan Basis data Sistem

1. Normalisasi

a) Bentuk Unnormal

\begin{tabular}{|l|l|}
\hline Kd bahan \\
Nm bahan \\
Bhn masuk \\
Bhn keluar \\
Jml bahan \\
Kd Supplier \\
Nm supplier \\
Nm Alamat \\
Alam \\
No tlpn \\
Tanggal \\
\end{tabular}

Gambar 6. Normalisasi Bentuk

Unnormal

b) Bentuk Normal Pertama (1NF)

$$
\begin{array}{|l}
\hline \text { Kd_bahan* } \\
\text { Nm_bahan } \\
\text { Bhn_masuk } \\
\text { Bhn_keluar } \\
\text { Jml_bahan } \\
\text { Kd_Supplier* } \\
\text { Nm_supplier } \\
\text { No_tlpn } \\
\text { Tanggal }
\end{array}
$$

Gambar 7. Normalisasi Bentuk Normal Pertama (1NF) c) Bentuk Normal Kedua (2NF)

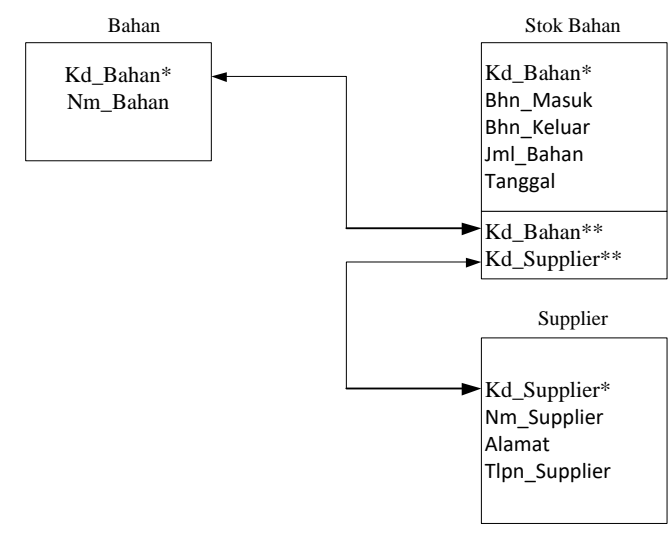

Gambar 8. Normalisasi Bentuk Normal Kedua (2NF)

d) Bentuk Normal Ketiga (3NF)

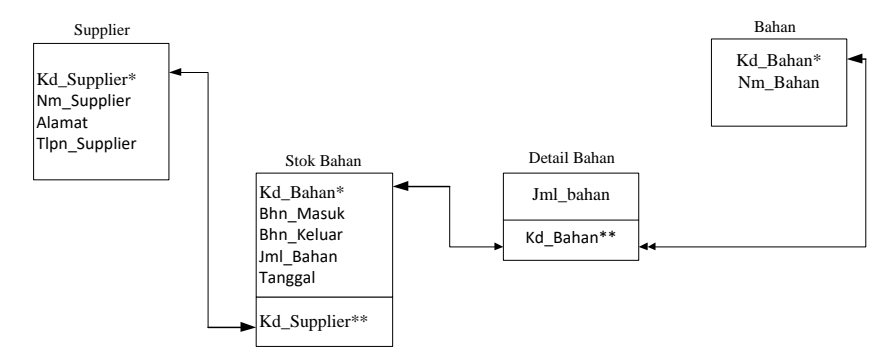

Gambar 9. Normalisasi Bentuk Normal Ketiga (3NF)
D. ERD

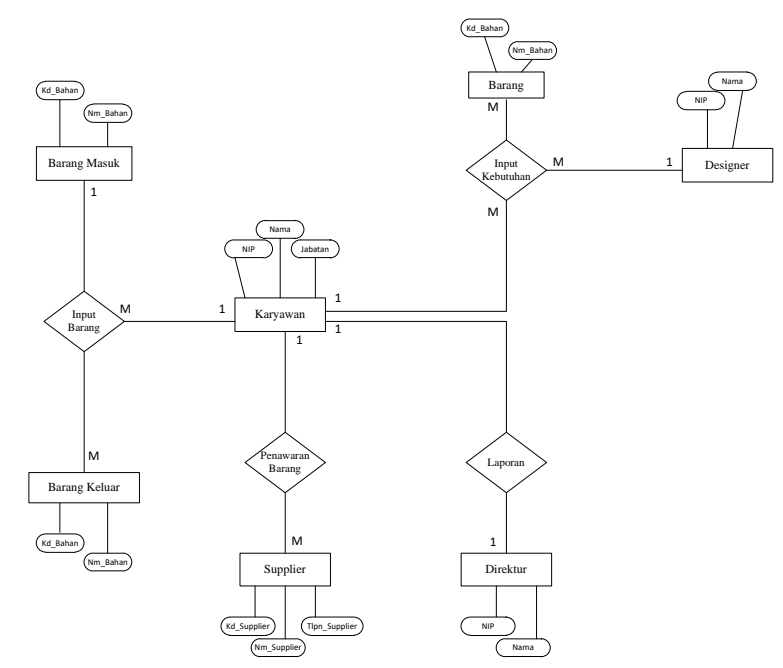

Gambar 10. Entity Relationship Diagram (ERD) 
E. Rancangan Layar, Rancangan Form Masukan Data, dan Rancangan Form Keluaran

1. Rancangan Layar

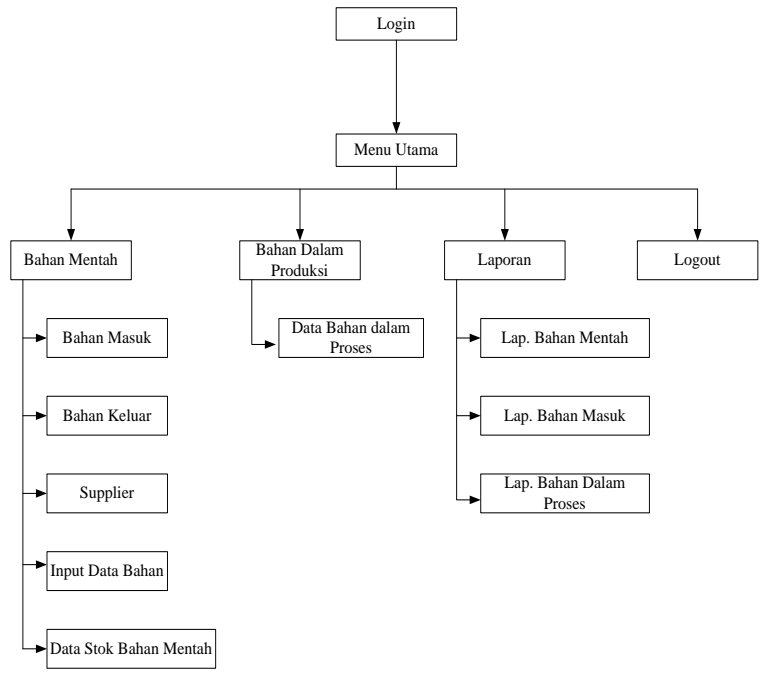

Gambar 11. Rancangan Layar

2. Rancangan Form Login

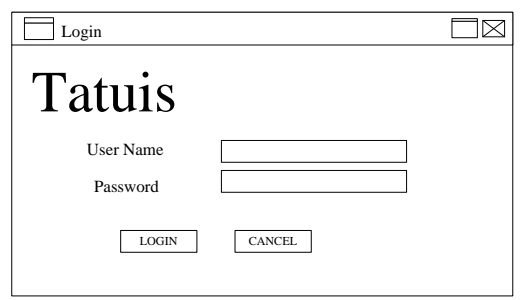

\section{Gambar 12. Rancangan Form Login}

3. Rancangan Form Menu

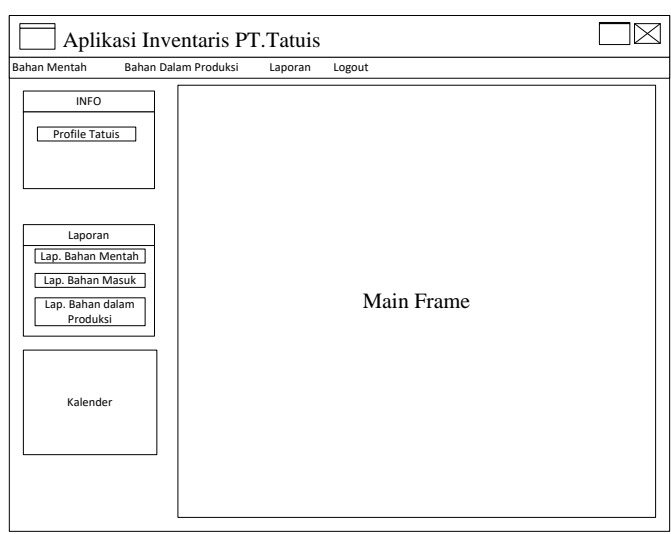

Gambar 13. Rancangan Form Menu
4. Rancangan Form Bahan Masuk

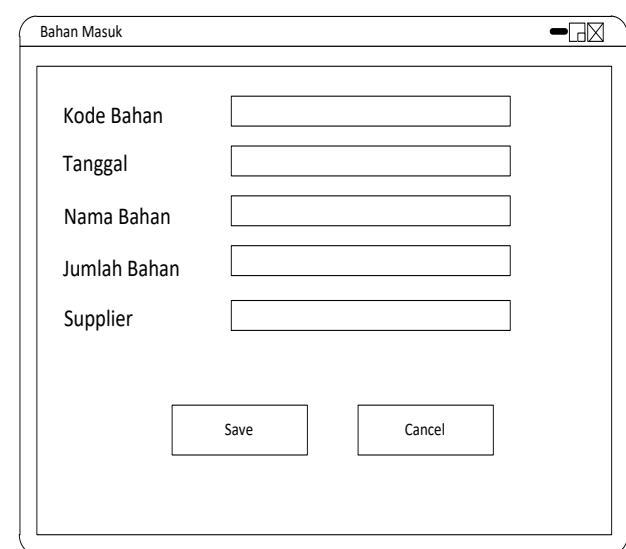

Gambar 14 Rancangan Form Bahan Masuk

5. Rancangan Form Bahan Keluar

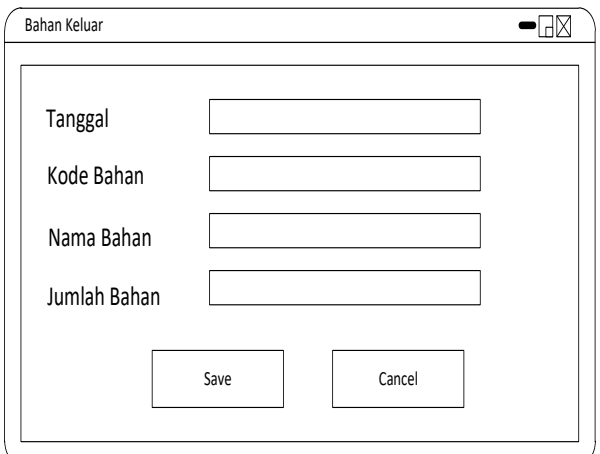

\section{Gambar 15. Rancangan Form Bahan} Keluar

6. Data Stok Bahan

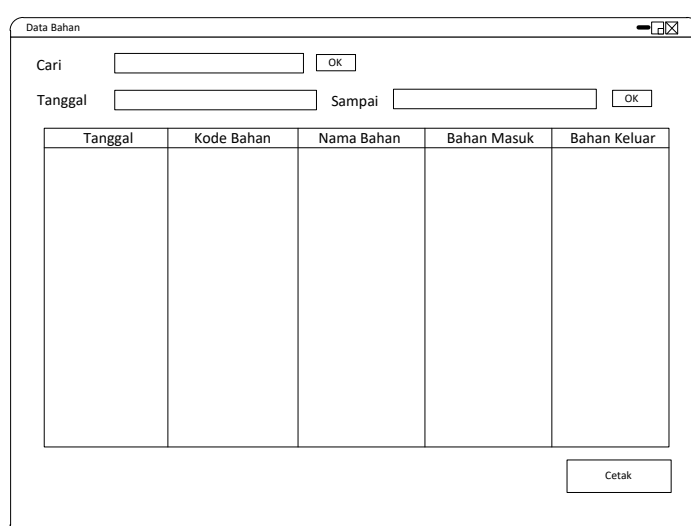

Gambar 17. Rancangan Data Stok Bahan 


\section{Data Stok Bahan Mentah}

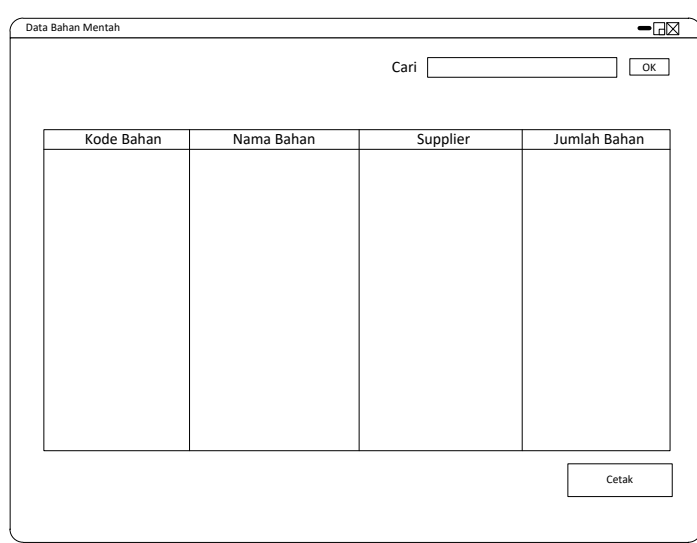

\section{Gambar 18. Rancangan Data Stok Bahan Mentah}

\section{F. Tampilan Layar}

Berikut tahap implementasi dan pengujian, dengan pembuatan menggunakan bahasa java pada editor netbeans.

1. Home

Pada halaman ini admin dapat memilih menu sesuai dengan kebutuhan admin.

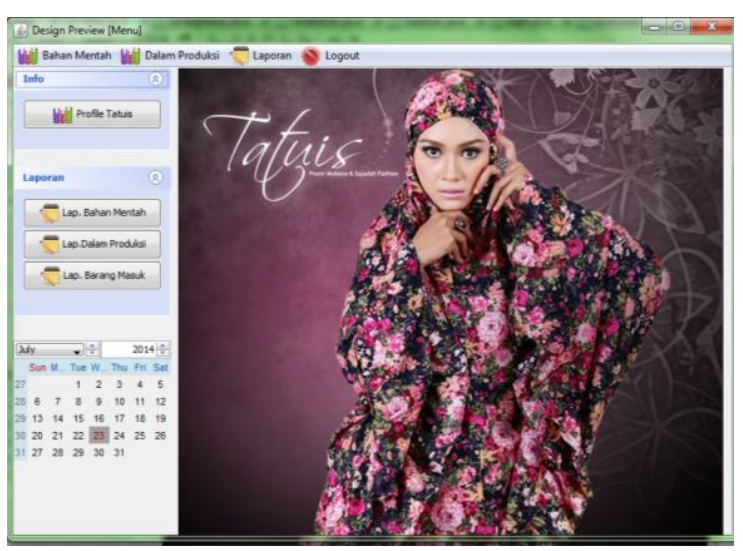

Gambar 19. Menu

\section{Form Bahan Masuk}

Pada menu ini admin dapat menambahkan stok bahan masuk kedalam sistem dengan mencari data sesuai dengan kode bahan.

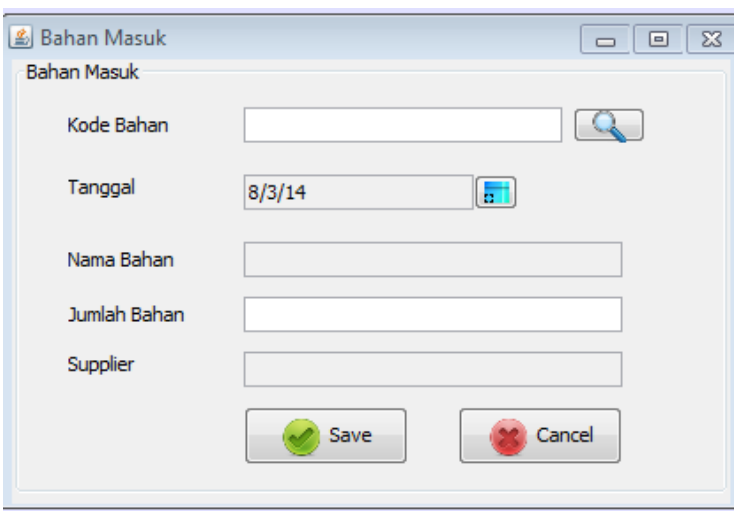

Gambar 20. Form Bahan Masuk

\section{Form Bahan Keluar}

Pada form ini admin dapat memasukan jumlah bahan keluar yang akan di produksi sesuai dengan kode bahan.

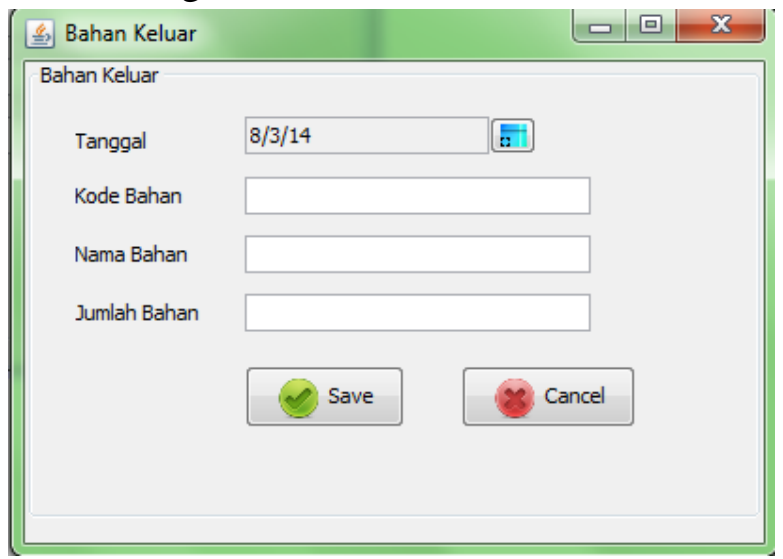

\section{Gambar 21. Form Bahan Keluar}

\section{Data Stok Bahan}

Pada form data stok bahan disini admin dapat melihat berapa saja jumlah stok bahan yang tersedia, serta berapa jumlah bahan keluar dan masuk. Pada stok bahan ini bahan dapat dicari sesuai dengan kode bahan dan dapat dilihat sesuai priode dari tanggal berapa sampai dengan tanggal berapa. stok data bahan memiliki laporan yang dapat di print sesuai dengan database yang tersimpan. 


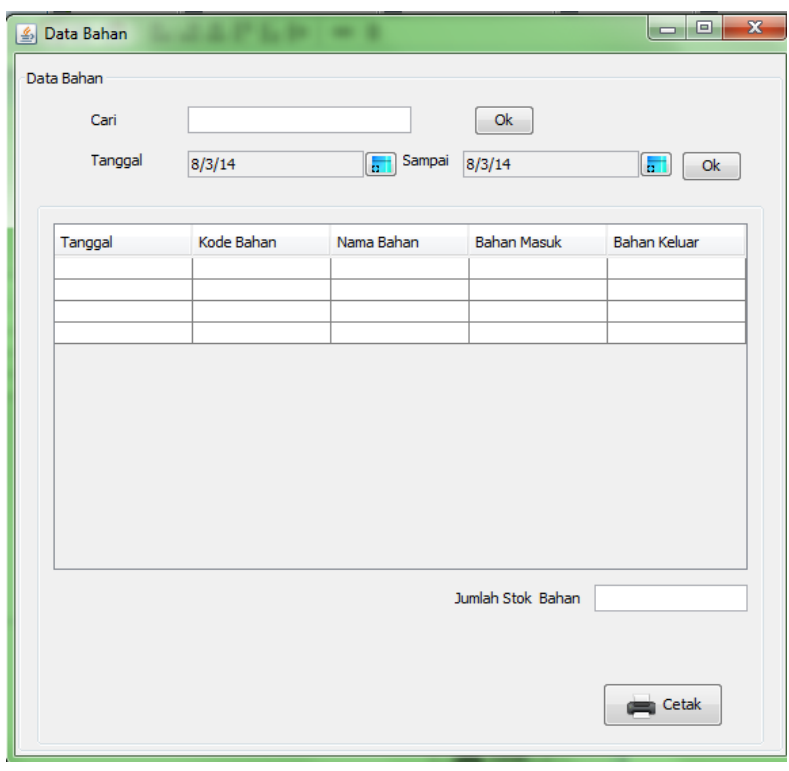

Gambar 22. Data Stok Bahan

\section{SIMPULAN}

Penulis telah membuat sebuah aplikasi berbasis komputer yang dapat mengatasi masalah pengolahan data inventaris di PT.Tatuis. Simpulan dari perancangan sistem aplikasi inventaris ini antara lain:

1. Data disimpan di database komputer sehingga keamanan database lebih baik.
2. Proses pencarian data dan pembuatan laporan dapat dilakukan dengan lebih akurat.

3. Pengolahan data lebih terstruktur sehingga pelayanan dapat lebih optimal dan cepat.

\section{DAFTAR PUSTAKA}

[1] Nugroho, Adi. Analisis dan Perancangan Sistem Informasi dengan Metodologi Berorientasi Objek. Bandung: Informatika. 2005.

[2] Kristanto, Andi. 2003. Perancangan Sistem Informasi dan Aplikasinya. Yogyakarta : Graha Ilmu.

[3] Sutanta Edhy. 2004. Sistem Database. Yogyakarta: Graha Ilmu.

[4] Sutabri, Tata .2005. Sistem Informasi Manajemen.2005. Jakarta.

[5] Nugroho, Bunafit. 2004. Database Relasional dengan MySQL. Yogyakarta: Andi Offset.

[6] Sigit W, Aloysius. 2010. 7 Proyek aplikasi dengan Java. Jakarta : Elex Media Komputindo 